\title{
Kinds and Distribution of Pythium Species Isolated from Soils in South Kinki District*
}

\author{
Tsuneo WATANABE**
}

\begin{abstract}
Soil samples from 28 locations (4-10 samples/Pref.) in South Kinki district were assayed for Pythium taxa by a trapping isolation method with cucumber seeds as a baiting substrate. One to seven taxa/sample (=location) were isolated or detected from 26 samples, but no Pythium was isolated from two samples from Wakayama prefecture. A total of 253 isolates were identified into 18 taxa including H-Zs, a provisional Pythium group with zoospore formation from hypha-like sporangia, but without sexual organs. Among these fungi, H-Zs was predominantly isolated from 20 samples, followed by $P$. sylvaticum, $P$. irregulare, $P$. ultimum, and $P$. aphanidermatum, all of which were isolated from 10-15 samples.
\end{abstract}

(Received October 17, 1992)

Key words: Pythium spp., kinds, distribution, soil, South Kinki district.

\section{INTRODUCTION}

Pythium is widely distributed all over the world ${ }^{6}$. In Japan, a series of papers concerned with kinds and distribution of Pythium species have been published, including Hokkaido Island ${ }^{24)}$, Tohoku district $^{23)}$, Shikoku Island ${ }^{20)}$, Kyusyu Island ${ }^{21)}$, the Ryukyu Islands ${ }^{22}$, and the piedmont natural forest at Mt. Fuji ${ }^{18)}$ during the past six years since 1985.

In this report, Pythium species from soils of Mie, Osaka, Wakayama, and Nara prefectures in South Kinki district were assayed, and the results are summarized.

\section{MATERIALS AND METHODS}

Samples and sampling. Soil samples were collected from 28 different locations of Mie, Osaka, Wakayama, and Nara prefectures in South Kinki district in September, 1982 (Table 1). They consisted of six samples from Mie, four from Osaka, ten from Wakayama, and eight from Nara with various habitats including cabbage (Brassica oleracea L.), chrysanthemum (Chrysanthemum morifolium Ramat.), cucumber (Cucumis sativus L.), eggplant (Solanum melongena L.), fig (Ficus carica L.), garland chrysanthemum (Chrysanthemum coronarium L.), ginger (Zingiber officinale Rosc.), iris (Iris sp.), kidney bean (Phaseolus vulgaris L.), muskmelon (Cucumis melo L.), onion (Allium cepa L.), pea (Pisum sativum L.), pumpkin (Cucurbita maxima Duch.), radish (Raphanus sativus L.), red pepper (Capsicum annuum L.), spinach (Spinacia oleracea L.), strawberry (Fragaria $\times$ ananassa Duch.), tomato (Lycopersicon esculentum Mill.), umbrella-pine (Sciadopitys verticillata (Thunb.) Sieb. et Zucc.), Welsh onion (Allium fistulosum L.) and Zanthoxylum (Zanthoxylum piperitum DC.), and soil $\mathrm{pH}$ values ranged from 4.7 to 7.5.

The respective soil samples were collected from five random cores from the top $15-\mathrm{cm}$ surface soil, and mixed thoroughly in polyethylene bags. These samples were usually assayed within 10 days after

* Part of this work was conducted at National Institute of Agricultural Sciences (Presently National Institute of Agro-Environmental Sciences).

** Forestry and Forest Products Research Institute, P.O. Box 16, Tsukuba Science City, Ibaraki 305, Japan 農林水産省森林総合研究所 
Table 1. Soil samples obtained from 28 different locations of South Kinki district with various habitats and soil $\mathrm{pH}$ values

\begin{tabular}{|c|c|c|c|c|c|}
\hline $\begin{array}{l}\text { Sample Location } \\
\text { no. }\end{array}$ & Habitat & $\mathrm{pH}$ & $\begin{array}{l}\text { Sample Location } \\
\text { no. }\end{array}$ & Habitat & $\mathrm{pH}$ \\
\hline \multicolumn{2}{|l|}{ MIE Pref. } & & \multicolumn{3}{|l|}{ OSAKA Pref. } \\
\hline 134 Ureshino & Cucumber & 6.6 & 140 Sayama & Tomato & 7.5 \\
\hline 135 Ureshino & Cabbage, Spinach & 6.1 & 141 Sayama & Radish & 5.3 \\
\hline 136 Mikumo & Fig & 5.9 & 142 Sayama & Eggplant & 6.5 \\
\hline 137 Misono & Chrysanthemum & 6.1 & Habikino & Onion & 6.5 \\
\hline 138 Misono & Chrysanthemum & 4.7 & & & \\
\hline 139 Misono & Chrysanthemum & 6.6 & WAKAYAMA Pref. & & \\
\hline \multicolumn{3}{|l|}{ NARA Pref. } & 145 Wakayama & $\begin{array}{l}\text { Garland } \\
\text { chrysanthemum }\end{array}$ & 6.1 \\
\hline 155 Kashihara & Welsh onion & 6.7 & Wakayama & Spinach & 6.8 \\
\hline 156 Kashihara & Muskmelon & 6.3 & Wakayama & Radish & 6.5 \\
\hline 157 Gojyo & Zanthoxylum & 6.1 & Wakayama & Iris & 5.3 \\
\hline 158 Gojyo & Eggplant & 7.0 & Wakayama & Ginger & 6.9 \\
\hline 159 Kouryou & Eggplant & 6.3 & Wakayama & Red pepper & 6.2 \\
\hline 160 Tenri & Spinach & 5.6 & Wakayama & Radish & 5.7 \\
\hline 161 Tenri & Kidney bean & 6.7 & Wakayama & Pumpkin & 6.6 \\
\hline \multirow[t]{2}{*}{162 Tenri } & Strawberry & 6.4 & Kouya & Umbrella-pine & 5.0 \\
\hline & & & Gobou & Pea & 6.4 \\
\hline
\end{tabular}

collection.

Isolations. Pythium was isolated by trapping methods using seeds of cucumber (cv. Tokiwajibai) as a trapping substrate following the previous works ${ }^{16,17,19)}$ in four separate experiments.

Ten seeds embedded in each $20-50 \mathrm{~g}$ soil sample in a 9-cm Petri dish incubated at $26^{\circ} \mathrm{C}$ for 1 day or $10^{\circ} \mathrm{C}$ for 5-10 days, respectively, were removed from soil, washed under running tap water for $1 \mathrm{hr}$, air-dried, and placed on water agar (WA) (2 seeds/plate). After a further incubation at $26^{\circ} \mathrm{C}$ for 1-3 days, pure isolates of Pythium spp. grown out of cucumber seeds on WA were obtained by single hyphal tippings.

Cultures and identifications. The fungi were cultured on various media including Difco corn meal agar (CMA) for mycological study. Several soaking solutions including Petri's salt solution were used to study asexual reproduction. All isolates were identified following the descriptions by the previous workers ${ }^{8-10,25)}$.

Most of the isolates in this study were stocked by T. Watanabe at the Forestry \& Forest Products Research Institute, or in the National Institute of Biological Resources, Ministry of Agriculture, Forestry \& Fisheries.

\section{RESULTS AND DISCUSSION}

\section{Distribution and notes of the fungi isolated}

A total of 253 Pythium isolates obtained from soils from 28 locations in Kinki district consisted of 142 isolates from cucumber seeds incubated at $26^{\circ} \mathrm{C}$, and 111 at $10^{\circ} \mathrm{C}$, and they were identified into 18 taxa including H-Zs (a provisional Pythium group with zoospore formation from hypha-like sporangia, but without sexual organ) and 15 unidentified isolates (Tables 1-3). The respective of 26 samples yielded one to seven taxa, but no Pythium was isolated or detected from two samples, i.e., garland chrysanthemum field soil (Sample 145), and red pepper field soil (Sample 150) at Wakayama (Tables 1 and 2). It is interesting to note that although Pythium was not isolated from Sample 150, three Phytophthora isolates were obtained from its sample. In two other samples (Sampes 140 and 157), four Phytophthora isolates were also obtained together with Pythium spp.

Pythium isolates in each taxon, and samples yielding each taxon are shown in Table 3. Pythium 
Table 2. Kinds of Pythium species and number of isolates obtained from soils of 28 different locations in South Kinki district

\begin{tabular}{|c|c|c|c|c|c|c|c|c|c|c|c|c|c|c|}
\hline \multirow{2}{*}{$\begin{array}{c}\text { Sample } \\
\text { no. }\end{array}$} & \multicolumn{13}{|c|}{ Kind of Pythium ${ }^{\text {a) }}$ and no. of isolates } & \multirow{2}{*}{$\begin{array}{c}\text { Miscella } \\
\text { neous }^{\text {b) }}\end{array}$} \\
\hline & aca & aph & car & ech & hyd & $\operatorname{irr}$ & oed & spi & syl & tor & ult & vex & $\mathrm{H}-\mathrm{Zs}$ & \\
\hline \multicolumn{15}{|l|}{ MIE Pref. } \\
\hline 134 & & 2 & & & & 1 & & 1 & 3 & 5 & & & 1 & \\
\hline 135 & & 3 & & & & 1 & & & 2 & & 1 & & 1 & P.sp.,1 \\
\hline 136 & & & & & & & 2 & & 2 & 1 & & 2 & & P.sp.,2 \\
\hline 137 & & 1 & & & & 1 & & & & 1 & 2 & 2 & 4 & \\
\hline 138 & & & & & & & & $+^{c)}$ & & & & & & \\
\hline 139 & & 4 & & & & & & & 1 & & 1 & & 6 & P.sp.,1 \\
\hline \multicolumn{15}{|c|}{ OSAKA Pref. } \\
\hline 140 & & & & & & & & & & & & & 2 & \\
\hline 141 & & & & & & & & 4 & & & 1 & & 6 & \\
\hline 142 & & 2 & 2 & 2 & & & & 1 & & & & & 2 & \\
\hline 143 & & 1 & & & & & & & 2 & 2 & & & 4 & P.sp.,2 \\
\hline \multicolumn{15}{|c|}{ WAKAYAMA Pref. } \\
\hline $\begin{array}{l}145 \\
146\end{array}$ & & & & & & & & & & & & & 1 & \\
\hline 147 & & & & & & & & & & & 2 & & & \\
\hline 148 & & & & & & 1 & & 1 & 1 & & & & 1 & P.sp.,3 \\
\hline 149 & & & & & & & & & 1 & 2 & 1 & 1 & 2 & Zin,6 \\
\hline \multicolumn{15}{|l|}{150} \\
\hline 151 & 1 & & & & & 6 & & & 1 & & & & & \\
\hline 152 & 1 & & & & & 1 & & & 1 & 1 & 1 & & 2 & \\
\hline 153 & & & 1 & & & 1 & 2 & & 4 & & & & & \\
\hline 154 & & 5 & & & & 1 & & & & & 4 & 2 & 2 & gra,1 \\
\hline \multicolumn{15}{|c|}{ NARA Pref. } \\
\hline 155 & & 3 & 1 & & 1 & & & & 1 & & 4 & & 3 & \\
\hline 156 & & & & 2 & & 3 & & & 5 & & 2 & & & \\
\hline 157 & 2 & & & 1 & & 1 & & & 4 & & & & 1 & $\begin{array}{l}\operatorname{dis}, 2 \\
\text { inf,1 }\end{array}$ \\
\hline 158 & & 3 & & & 2 & & & & & 1 & 3 & & 3 & \\
\hline 159 & & & & & & 3 & & 2 & 1 & & & & 4 & P.sp.,3 \\
\hline 160 & & & 1 & & & 1 & 3 & & 1 & 1 & & & 1 & spl,1 \\
\hline 161 & & & & & & 8 & 1 & & & & 1 & 1 & 4 & P.sp.,1 \\
\hline 162 & & 3 & 3 & & & & 7 & & & & & & 2 & P.sp.,2 \\
\hline Total isol. & 4 & 27 & 8 & 5 & 3 & 29 & 15 & 9 & 30 & 14 & 23 & 8 & 52 & 26 \\
\hline
\end{tabular}

a) Abbreviated as follows: aca $=P$. acanthophoron, $a p h=P$. aphanidermatum, car $=P$. carolinianum, dis $=P$. dissotocum, ech $=P$. echinulatum, gra $=P$. graminicola, hyd $=P$. hydonosporum, inf $=P$. inflatum, irr $=P$. irregulare, oed $=P$. oedocephalum, spi $=P$. spinosum, $\mathrm{spl}=P$. splendens, $\mathrm{syl}=P$. sylvaticum, tor $=P$. torulosum, ult $=P$. ultimum, vex $=P$. vexans, $\mathrm{zin}=P$. zinjiberum, $\mathrm{H} \cdot \mathrm{Zs}_{\mathrm{s}}=\mathrm{a}$ provisional Pythium group with zoospore formation from hypha-like sporangia, but without sexual organs.

b) Isolated only from one location (sample), or unidentified species (=P.sp.).

c) Detected on the isolation plates, but not studied further.

aphanidermutum (Edson) Fitz. and P. zinjiberum Takahashi were isolated from cucumber seeds incubated only at $26^{\circ} \mathrm{C}$, but others at both 26 and $10^{\circ} \mathrm{C}$.

Of 42 isolates with lobate sporangia, 27 of $P$. aphanidermatum collected in 10 locations and 14 of $P$. torulosum Coker \& Patterson from eight locations discharged zoospores during this study, but one isolate of $P$. inflatum Matthews never discharged zoospores.

Six isolates each obtained from the ginger field at Wakayama (Sample 149) and the rotted rhizome of ginger concomitantly studied were all identical. These fungi formed lobate sporangia (nearly $10 \mu \mathrm{m}$ wide) with long exit tubes (nearly $200 \mu \mathrm{m}$ long), and oogonia often with one to two papillae, and two to 
Table 3. List of Pythium isolates obtained from soils from South Kinki district, and samples yielding each taxon, indicated by isolate numbers and parenthesized numbers, respectively

P. acanthophoron (four isolates): 82-744(151);-750(152);-785,-792(157)

P. aphanidermatum (27 isolates): 82-657,-658,-659(135);-672(137);-685(139);-700,-701(142);-711(143);-761,-765(154);-768, -769(155);-795,-796,-803(158);-982,-983(134);-984,-985,-986(139);-987,-988,-989(154);-990,-991,-992(162);-996(155)

P. carolinianum (eight isolates): 82-702,-703(142);-758(153);-774(155);-813(160);-976,-977,-981(162)

$P$. dissotocum (two isolates): $82-945,-946(157)$

P. echinulatum (five isolates): 82-780,-781(156);-786(157);-878,-879(142)

P. graminicola (one isolate): $82-762(154)$

P. hydnosporum (three isolates): 82-771(155);-798,-799(158)

P. inflatum (one isolate): $82-787(157)$

P. irregulare (29 isolates): 82-670(137);-722(148);-739,-740,-741(151);-748(152);-777,-779(156);-808,-810(159);-819,-820,-821, -825(161);-838(134);-847(135);-907,-908,-909(151);-923(153);-927(154);-942(156);-948(157);-959(159);-963(160);-967,-968, $-970,-972(161)$

P. oedochilum (15 isolates): 82-751,-752(153);-815,-818(160);-822(161);-828,-829,-830,-831,-832,-834(162);-853,-854(136); $-964(160) ;-980(162)$

P. spinosum (nine isolates): 82-694,-695(141);-806,-807(159);-839(134);-874,-875(141);-880(142);-890(148)

P. splendens (one isolate): $82-997(160)$

P. sylvaticum (30 isolates): 82-653(134);-665,-669(136);-713(143);-742(151);-754(153);-784(156);-814(160);-836,-840(134); $-845,-846(135) ;-870(139) ;-884(143) ;-891(148) ;-901(149) ;-913(152) ;-920,-921,-922(153) ;-935(155) ;-938,-939,-940,-941(156)$; $-947,-949,-950,-951(157) ;-960(159)$

P. torulosum (14 isolates): 82-648,-649,-650,-651(134);-666(136);-707(143);-802(158);-842(134);-863(137);-883(143);-897, -898(149);-916(152);-966(160)

P. ultimum (23 isolates): 82-671(137);-687(139);-717(147);-759,-760(154);-767,-773(155);-778(156);-862(137);-873(141); -888(147);-902(149);-912(152);-925,-926(154);-933,-934(155);-937(156);-954,-955,-956(158);-969(161);-995(135)

P. vexans (eight isolates); 82-664,-668(136);-675,-678(137);-763,-764(154);-903(149);-973(161)

P. zinjiberum (six isolates): 82-724,-725,-726,-727,-730,-731(149)

H-Zs (52 isolates): 82-652(134);-673,-674(137);-682,-683,-684(139);-688,-689(140);-692,-693,-697,-698(141);-705,-709(143); -770(155);-791(157);-797(158);-804,-805(159);-823,-824(161);-848(135);-859,-860(137);-867,-868,-869(139);-871,-872(141); $-876,-877(142) ;-881,-882(143) ;-886(146) ;-892(148) ;-899,-900(149) ;-914,-915(152) ;-928,-929(154) ;-931,-932(155) ;-952$, $-953(158) ;-957,-958(159) ;-965(160) ;-971(161) ;-978,-979(162) ;-994(161)$

Unidentified Pythium spp.(15 isolates): 82-667(136);-686(139);-706,-710(143);-720,-721,-723(148);-811,-812(159);-844(135); $-855(136) ;-961(159) ;-974,-975(162) ;-993(161)$

three diclinous antheridia (per oogonium) which occasionally coiled around the oogonial stalk and oogonia, bearing single aplerotic oospores. Its oogonia were often aborted. In addition, they were often directly connected to lobate sporangia. This fungus was tentatively identified as $P$. zinjiberum ${ }^{7,122}$.

Of 54 isolates with zoospore formation from hypha-like sporangia, two from one location were $P$. dissotocum Drechsler and the rest of 52 from 20 locations were H-Zs. Predominance of H-Zs is interesting to note, because in four other areas ${ }^{20-24)}$, this taxon' was not so common, and one to five samples in each district yielded this taxon.

Of all of 31 isolates with zoospore formation from sphaerosporangia, eight each were identified as $P$. carolinianum Matthews, and $P$. vexans de Bary, and 15 tentatively identified as $P$. oedochilum Drechsler, although its internal proliferation of sporangia was not observed in this study.

Of a total of 48 isolates with echinulate oogonia, 29 from 13 locations were $P$. irregulare Buisman with 1-3 protuberances on oogonia, nine from five locations, $P$. spinosum Sawada with numerous digitate protuberances, all over the oogonia, four from three locations, $P$. acanthophoron Sideris with short protuberances (less than $3 \mu \mathrm{m}$ long) on oogonia bearing single plerotic oospores and inflated clavate, or papillate antheridia, often with one to two constrictions, making broad oogonial contact, in which spherical hyphal swellings (conidia) were not formed, five from three locations, $P$. echinulatum Matthews with sharp protuberances (up to $7.5 \mu \mathrm{m}$ long) on oogonia, together with hypogynous, monoclinous or diclinous antheridia, single plerotic oospores, and spherical hyphal swellings which were discrete, and occasionally catenulate, and three from two locations, P. hydnosporum (Mont.) Schroeter with sharp protuberances (up to $5 \mu \mathrm{m}$ long) on oogonia, together with single aplerotic oospores, and inconspicuous- 
ly hypogynous antheridia, in which hyphal swellings were not formed. Isolates of $P$. echinulatum were tentatively identified, because they never discharged zoospores. This fungus was not recorded in the previous works ${ }^{16-24)}$. In addition, $P$. spinosum was detected from Sample 138 on the isolation plates, but no further work was conducted.

Twenty three isolates from 12 locations formed smooth oogonia with hypogynous or sessile antheridia, aplerotic oospores, and spherical hyphal swellings without zoospore formation, and they were identified as $P$. ultimum Trow.

Of 31 isolates with spherical hyphal swellings (conidia), 30, the conidia of which were $20-25 \mu \mathrm{m}$ in diam, were tentatively identified as $P$. sylvaticum Campbell \& Hendrix ${ }^{2}$, and one, the conidia of which exceeds $35 \mu \mathrm{m}$ in diam as $P$. splendens Braun. Of $30 P$. sylvaticum isolates, five occasionally formed sexual organs with aplerotic oospores and two to three or more diclinous antheridia per oogonium (homothallic isolates $\left.{ }^{2,4}\right)$, but others did not form sexual organs (heterothallic isolates).

Predominance of Pythium taxon, H-Zs, and isolation of as many as 18 taxa in Kinki district were characteristic in comparison with Pythium studied in five other districts ${ }^{18-24)}$ in Japan (Tables 2 and 3).

Of the 15 unidentified isolates, 11 formed lobate hyphal swellings, and among these, seven discharged zoospores, but others did not. The rest of four isolates just formed aseptate hyphae, but never discharged zoospores.

Most of the 18 taxa identified in this study were recorded previously ${ }^{16-24)}$ in Japan, and also in other countries $^{1,3,5,8-11,13-15,26)}$.

I wish to thank Mr. S. Nagae, Mr. Y. Tagami, Mr. A. Tomikawa, Mr. Y. Tanaka, Mr. T. Kagi, Mr. S. Kusakari, Mr. A. Nakano, Mr. H. Iemura, Mr. A. Yoshioka, and Mr. T. Kodama in Mie, Osaka, Wakayama and Nara Prefectural Agricultural Experiment Station for their help in collecting soil samples in 1982.

\section{Literature cited}

1. Campbell, W.A. and Hendrix, F.F., Jr. (1967). Pythium and Phytophthora species in the southeastern United States. Plant Dis. Reptr. 51: 929-932.

2. Campbell, W.A. and Hendrix, F.F., Jr. (1967). A new heterothallic Pythium from southern United States. Mycologia 59 : 274-278.

3. Dick, M.W. and Ali-Shtayeh, M.S. (1986). Distribution and frequency of Pythium species in parkland and farmland soils. Trans. Br. mycol. Soc. 86 : 49-62.

4. Hendrix, F.F., Jr. and Campbell, W.A. (1968). Pythiaceous fungi isolated from southern forest nursery soil and their pathogenicity to pine seedlings. Forest Science $14: 292-297$.

5. Hendrix, F.F., Jr. and Campbell, W.A. (1970). Distribution of Phytophthora and Pythium species in soils in the continental United States. Can. J. Bot. 48: 377-384.

6. Hendrix, F.F., Jr. and Campbell, W.A. (1973). Pythiums as plant pathogens. Ann. Rev. Phytopath. $11: 77-$ 98.

7. Ichitani, T. and Shinsu, T. (1980). Pythium zingiberum causing rhizome rot of ginger plant and its distribution. Ann. Phytopath. Soc. Japan $46: 435-441$.

8. Matthews. V.D. (1931). Studies on the genus Pythium. Univ. N. Carol. Press, Chapel Hill.

9. Middleton, J.T. (1943). The taxonomy, host range and geographic distribution of the genus Pythium. Mem. Torrey bot. Club $20: 1-171$.

10. Plaats-Niterink, A.J. van der (1981). Monograph of the genus Pythium. Studies in Mycology (CBS) 21:1242.

11. Robertoson, G.I. (1980). The genus Pythium in New Zealand. N.Z.J. Bot. 18: 73-102.

12. Takahashi, M. (1954). On the morphology and taxonomy of some species of the genus Pythium which cause crop diseases. Ann. Phytopath. Soc. Japan 18:113-118.

13. Teakle, D.S. (1960). Species of Pythium in Queensland. Qd. J. agric. Sci. 17: 15-31.

14. Vaartaja, O. and Bumbieris, M. (1964). Abundance of Pythium species in nursery soils in South Australia. Aust. J. Biol. Sci. 17 : 436-445.

15. Warcup, J.H. (1952). Effect of partial sterilization by steam and formalin on damping-off of sitka spruce. Trans. Brit. mycol. Soc. $35: 248-262$.

16. Watanabe, T. (1981). Distribution and populations of Pythium species in the northern and southern parts of Japan. Ann. Phytopath. Soc. Japan 47 : 449-456. 
17. Watanabe, T. (1983). Distribution of Pythium aphanidermatum in Japan: its significance. Trans. mycol. Soc. Japan $24: 15-23$.

18. Watanabe, T. (1985). Pythium species found in the piedmont natural forest at Mt. Fuji. Trans. mycol. Soc. Japan $26: 41-45$.

19. Watanabe, T. (1985). Distribution and ecology of Pythium species in Japan. Plant Prot. Bull. (Taiwan, R. O.C.) $27: 211-224$.

20. Watanabe, T. (1988). Kinds and distribution of Pythium species isolated from soils in Shikoku Island. Ann. Phytopath. Soc. Japan $54: 523-528$.

21. Watanabe, T. (1989). Kinds, distribution and pathogenicity of Pythium species isolated from soils of Kyushu Island. Ann. Phytopath. Soc. Japan $55: 32-40$.

22. Watanabe, T. (1989). Further study on Pythium species isolated from soils in the Ryukyu Islands. Ann. Phytopath. Soc. Japan $55: 349-352$.

23. Watanabe, T. (1990). Kinds and distribution of Pythium species isolated from soils in Tohoku District. Ann. Phytopath. Soc. Japan $56: 88-91$.

24. Watanabe, T. (1990). Kinds and distribution of Pythium species isolated from soils in Hokkaido Island. Ann. Phytopath. Soc. Japan $56: 549-556$.

25. Waterhouse, G.M. (1968). The genus Pythium. Diagnoses (or descriptions) and figures from the original papers. Mycol. Pap. $110: 1-50$

26. Yu, Y.-N. and Ma, G.-Z. (1989). The genus Pythium in China. Mycosystema 2: 1-110.

\section{和 文 摘 要}

\section{渡辺恒雄：南近畿地方の土壤から分離したPythium菌の種と分布}

南近畿地方の土壤に生息するPythium菌の種と分布を明らかにするため, キュウリ種子による捕捉法を用いて菌を 分離し, 調查した。供試した 28 試料中 26 試料から 1 試料当り 1 ～種のPythium 菌が分離または検出されたが, 2 試料 からは全く分離できなかった。分離した合計 253 菌株は, H-Zs (糸状胞子囊から遊走子を形成するが, 生殖器官は未形 成の一群)を含む 18 種に分類・同定できた。最も一般的に分布していたH-Zsは, 20 力所から 52 菌株が分離された。次 いで, P. sylvaticum, P. irregulare, P. ultimum, P. aphanidermatumの分布が広く, 10〜15 カ所から 23〜30 菌株が分 離された。 